\title{
Echo from the underground: the heritage customization of subway infrastructures in Shanghai's listed areas
}

\author{
Plácido González Martínezi]
}

\begin{abstract}
The design of metro stations constitutes a clear example of the new core role of culture in a city such as Shanghai that remains to be assessed from a critical heritage perspective. As an unexplored dimension of a massive heritage institutional apparatus, metro stations act as 'white canvases' where commercial, political and cultural messages are displayed. These messages contribute to city branding while simultaneously influencing the perception and interpretation of the historic urban landscape above ground. This research offers insights into the subway stations located in the listed heritage areas of Shanghai and the architectural, artistic and exhibitive resources that 'give character' to these stations. The research applies visual methods and discursive analysis based on direct observation of these 'characteristic' elements in metro stations. The paper establishes the argument that the amount and distribution of these characteristic elements in the metro network offers unequal representation of the importance of the heritage areas above. When represented, we argue that such features convey renewed narratives of urban identity according to an authorised heritage discourse in Shanghai. These narratives cater to an image of ideal, harmonious continuity between the past and the future that aims to characterise Shanghai as a Chinese global metropolis.
\end{abstract}

Keywords: Underground station design, Infrastructures in listed areas, Authorised heritage discourse, Heritage conservation in Shanghai, City branding

\section{Introduction}

This paper explores the role of design features in metro stations as conveyors of an authorised heritage discourse in Shanghai. Research on metro stations has tended to prefer examination of architectural and urban design aspects (Labbé 2016; Li et al. 2015; Sun et al. 2015), and the historical, cultural and heritage dimensions of these stations remain understudied. Serving as key interfaces between modern urban infrastructures and the historic urban landscape (Huybrechts 2018), metro stations are among the most ubiquitous channels for the transmission of authorised heritage discourses. Due to their universal reach, they should be considered as compulsory

Correspondence: placido@tongji.edu.cn

Tongji University, College of Architecture and Urban Planning, 1239 Siping Road, Shanghai 200092, China museums, 'white canvases', available for urban growth coalitions to support developmental narratives.

The relationship between infrastructural and heritage development is ambivalent: in general, subway construction has direct negative effects through the destruction of archaeological heritage (Lambertucci 2016, 2018) and on the built heritage above ground in the form of vibrations during construction and operation (UNESCO 1976). Additionally, subways contribute to economic changes that may alter the social balance of heritage urban areas. However, metro infrastructures have also been deemed central to the preservation of the aboveground urban landscape, sparing it from the widening of historic roads and streets to serve public transportation and enabling the rise of tourism, leisure and cultural activities by increasing access to historic neighbourhoods.

(c) The Author(s). 2021 Open Access This article is licensed under a Creative Commons Attribution 4.0 International License, which permits use, sharing, adaptation, distribution and reproduction in any medium or format, as long as you give appropriate credit to the original author(s) and the source, provide a link to the Creative Commons licence, and indicate if changes were made. The images or other third party material in this article are included in the article's Creative Commons licence, unless indicated otherwise in a credit line to the material. If material is not included in the article's Creative Commons licence and your intended use is not permitted by statutory regulation or exceeds the permitted use, you will need to obtain permission directly from the copyright holder. To view a copy of this licence, visit http://creativecommons.org/licenses/by/4.0/. 
Metro infrastructures have grown exponentially in China since the 1990s. This development happened simultaneously with the rise in conservation initiatives for urban heritage in Chinese cities. Inaugurated in 1993, the Shanghai metro network is the second longest in the world, with 17 lines, 413 stations and a total length of $705 \mathrm{~km}^{2}$. The 12 Shanghai cultural and historic areas identified and listed in 2003 by the Shanghai Municipal Government are a pioneering attempt to establish area protection in China. ${ }^{1}$ The superposition of both urban transportation and heritage conservation systems was completed in 2013, when all heritage listed areas were served by at least one metro station within or bordering their limits.

In the context of place promotion and city branding, metro stations provide immediate signs of the significance of urban locations. Stations act as gates for locals and tourists, creating the opportunity for identity construction and visitor appreciation. At the same time, by means of customisation, stations become an underground 'parallel heritage city', not only reflecting the historic environment above ground but also becoming a powerful tool for the dissemination of the authorised heritage discourses that guide heritage appreciation. This paper examines the cultural heritage features of customised metro stations in Shanghai, posing the following questions: What are the narratives supported by these features? Are these narratives equally represented in metro stations? Do the narratives just focus on the past, or do they also formulate the future image of a global city?

The methodological choice in answering these questions is based on a Foucauldian assumption: discourses and the narratives that support them serve certain regimes of truth that determine ways of thinking and acting. For this reason, this research focuses on the social

\footnotetext{
${ }^{1}$ The definition of these sites was based on historic, cultural and environmental values that aim to encompass a contemporary characterization of the history of Shanghai. The origins of the city are represented in Laochengxiang, which corresponds to the historic settlement before the Nanjing Treaty in 1842. Waitan (the Bund) represents the financial prowess of the city during the time of the concessions. People's Square holds a symbolic meaning as an open space and as the current seat of the city government. West Nanjing Road is representative of the commercial bustle of the city. The contours of the Hengshan Road - Fuxing Road area largely correspond to the location of the former French Concession of Shanghai. Yuyuan Road, Xinhua Road and Hongqiao are representative, highly qualified suburban locations of the 1930s. Shanyin Road has an artistic and literary atmosphere in a highly qualified environment, whereas Jiangwan is a display of modern planning and architecture in what was meant to be the new civic centre of the city in the 1930s:

Wujiaochang. Tilanqiao holds the sad memories of exile, connecting Shanghai with the international dimension of World War 2, whereas Longhua Road offers a turn to tradition with the imposing image of the pagoda, and to Communism with the memory of the Longhua Martyrs.
}

production of images, which require visual methods for discourse analysis. This encompasses a qualitative analysis of visual data related to architectural features, artistic and applied arts artefacts, and exhibitions incorporated into the layout of metro stations. The purpose of this discourse analysis is to study the institutional use of culture as a tool of social management (Rose 2007), which is closely related to promoting the conservation and protection of urban heritage.

The method also considers that metro stations are not museums or galleries and thus were not originally intended for the display of images but adapted for this purpose instead. For this reason, and again in Foucauldian terms, the study of the apparatus is privileged over the technologies of display. With this goal, this study focuses on the stations located within or in the limits of the 12 cultural and historical listed areas of Shanghai. Fieldwork took place between September and November 2019 and consisted of visits to 40 stations. The stations' architectural features, together with the displayed elements, were documented through photographs, videos and notes. This fieldwork was performed by the author together with students of the course on Heritage Management and Legislation at the College of Architecture and Urban Planning of Tongji University.

This paper will first elaborate a review of the literature on the relationship between metro infrastructure and heritage areas and the heritage implications of the customised design of metro stations. Second, it will characterise the stations of the Shanghai metro system based on their chronology, location and narratives, analysing the representativeness of the heritage listed areas and the favouring of certain topics over others in response to authorised heritage discourses on the city. The paper will then discuss these findings, establishing the argument that the 'underground' authorised heritage discourse displayed in the Shanghai metro stations caters to the purposes of state-led developmentalism and official aims for a harmonious society.

\section{The underground system as a new heritage frontier}

2.1 Transmission channels for China's 'heritage fever'

Our work is embedded in a wider body of research addressing the rising importance of heritage as a tool of governance in contemporary China. Authors such as Oakes (2019) have already highlighted the use of heritage to generate social cohesion and promote modernisation and development. Recent contributions from Svensson and Maags (2018); Ludwig and Walton (2020); Zhu (2019); and Zhu and Maags (2020) have built a consistent analysis of how this instrumentality of heritage responds to economic and political concerns about legitimacy, solidarity and harmony. Ludwig and Walton 
(2020) referred to the importance of heritage for the rebuilding of moral values in the private realm and the shaping of a national identity among the public. Interestingly, these authors also argue that the effects of China's 'heritage fever' go well beyond its national borders, strongly influencing heritage practices of documentation, conservation and dissemination in the international sphere (Ludwig and Walton 2020; Zhu and Maags 2020).

These studies also all agree on the importance of the use of heritage at a local level as a means to promote economic growth (Svensson and Maags 2018; Zhu 2019). Aligning with Ashworth and Karavatzis' (2011) studies on heritage and city branding, authors such as Jansson and Lagerkvist (2009), Law (2012), and Law and Qin (2017) have reflected on the adaptation of historical narratives in China in the context of global and regional competition between cities. Despite the proliferation of studies in this respect, with the most recent contributions from Zhu (2020) studying the case of Xi'an or Law and Qin (2017) in the city of Wuhan, the greatest share of attention from researchers has focused on the city of Shanghai. Authors such as Pan $(2005,122-137)$ and Law (2012) have insightfully shown how the global branding of Shanghai has required a complete re-interpretation of its semi-colonial past, now associated with images of economic success and prosperity. Ren (2008) and González Martínez $(2017,2019,2020)$ have studied the consequences of this re-interpretation for the commodification of historic neighbourhoods. However, the impact of Shanghai's 'heritage turn' in less easily perceived areas of its built environment, such as infrastructure, remains to be addressed.

This is where our study finds an important gap. Although Wu (2004) conducted comprehensive research on the cultural strategies of Shanghai on its path to join the ranks of global cities, the place-oriented measures that she studied referred to 'infrastructures' as cultural venues such as museums and theatres. Her inquiry, as well as Wang's (2009), Larsen's (2014) and Zhong's (2015) on the incorporation of public arts and the revitalisation of historic buildings and public spaces, did not address the key question of the spaces of mass transit. The metro infrastructures of Shanghai, which act as involuntary museums' with undeniable effects on the perceptions of millions of citizens and tourists, require explicit study and attention.

\subsection{Underground stations as spaces for display, from scientific to socio-political connotations}

The literature on metro station design shares common ground on aesthetic concerns and aims to counteract 'negative fantasies' and enhance the psychological comfort of metro users (Sun et al. 2015; Labbé 2016;
Lambertucci 2018). This pragmatic approach to design is symptomatic of the so-called 'black box' condition of infrastructure in contemporary urban discourse (Domínguez Rubio and Fogué 2013), by means of which technical knowledge prevails over any kind of consideration towards citizenship. Accordingly, when referring to the aesthetisation of metro infrastructures, we contend that it constitutes a clear example of the top-down production of an authorised heritage discourse (Smith 2006).

The artistic display and design of metro stations is consubstantial to the history of metropolitan underground transportation: the London, Paris and Budapest metros shared the significant reformist political purpose of bringing the arts to the commuting masses (Clendenin 2008). The ultimate manifestation of authorised discourses appears in the subterranean 'palaces of the people' built in Moscow in the 1930s through 1950s (O'Mahony 2003; Ryklin 2014). According to Gabriel (2018), Moscow's counterpart in Pyongyang exemplifies the detachment of the metro system from the city above, with the purpose of intensifying 'underground' messages of political legitimation and building an autonomous narrative. Despite being frequently overlooked, the role of the arts and design in metro stations is still to cater to the political and economic purposes of place branding, with an important heritage dimension. Since the Louvre metro station in Paris started to showcase items from the museum above ground in the 1970s, the promotion of cultural narratives has also served to promote social exclusion, as shown by Reynolds's (2012) study of the 'glamourisation' of Hollywood/Vine station and its relationship with the gentrification of the Hollywood area in Los Angeles.

Although it focuses on the conflict between modernisation and conservation, the mainstream heritage conservation doctrine has frequently overlooked the relationship between metro infrastructure and heritage. ${ }^{2}$ Recent contributions beyond the realm of heritage charters and recommendations have highlighted alternative approaches to the specific question of archaeological sites. Lambertucci's

\footnotetext{
${ }^{2}$ Since the Athens Charter (1931) first mentioned the visually disruptive effect of telegraph poles, heritage charters and recommendations have systematically downplayed the impact of urban infrastructure (ICOMOS 1964; ICOMOS 1994; ICOMOS 2003a, b), most often highlighting its aesthetic impact on the urban landscape (UNESCO 1976; ICOMOS 1987; UNESCO 2005; ICOMOS 2005; UNESCO 2005) and focusing on the negative effects of road construction and vehicular traffic (UNESCO 1968; UNESCO 1976; ICOMOS 1987; UNESCO 2005; UNESCO 2011). One exception is the 1968 Recommendation on the Impact of Public and Private Works (UNESCO 1968), which refers to the potential risk of destruction of archaeological sites in the shape of 'mining, quarrying, and dredging', implicitly referring to metro infrastructures. Only the 1976 Nairobi Recommendation (UNESCO 1976) and the 1987 Washington Charter (ICOMOS 1987) highlighted the potential impact of metro infrastructures (as well as any other underground infrastructural construction) on cultural properties, but just in terms of vibrations.
} 
study on the San Giovanni 'archaeostation' in Rome offers an example of how the display of archaeological remains becomes a 'resource' for the underground and a means for place branding (Lambertucci 2013, 2016, 2018). Fouseki and Sandes (2009) develop an engaged analysis of Dafni Station in Athens from the perspective of theory, pointing at the use of archaeological replicas in approximate stratigraphic arrangements as a key shift from material authenticity to the production of an 'authentic' experience for visitors (Fouseki and Sandes 2009, 49).

The literature on the design of metro stations in China has a general pragmatic orientation, highlighting the need to counteract the negative effects of a lack of light and overcrowding, with occasional references to the psychological effects of materiality and design (Zhuang 2000). Following a normative approach, authors such as Sun et al. (2015) and Li et al. (2015) have raised the issue of the architectural characterisation of metro stations in Beijing and Xi'an, with regional culture as a source of inspiration, but both focus more on the aesthetic dimension than on a critical inquiry into the displayed narratives. Zhu et al. (2011) adopted a more in-depth analytical stance about the purposes of city marketing, focusing on place-related advertising in the metro system of Guangzhou, even though they also encompassed the design principles of metro stations. Therefore, a critical assessment of the heritage customisation of metro stations in China remains a major knowledge gap.

\section{The Shanghai metro under listed areas as a case study}

Even if researchers such as Zhu et al. (2011) have used a mix of quantitative and qualitative analyses for the case of the Guangzhou metro, we contend that the qualitative perspective offered by visual methods and discourse analysis is more appropriate for the characterisation of underground heritage narratives. Our analysis focuses on the architectural and artistic features of the Shanghai metro stations located within the limits or within the 12 'Cultural and Historically Significant Heritage Areas of Shanghai' listed in 2003. Considering that the Shanghai metro serves an average of 10 million riders every day, these stations act as privileged gates for both the local population and visitors to heritage areas. In our study, we contend that metro stations in listed areas act as devices, by means of both what they incorporate and what they omit, for presenting and interpreting the urban heritage above ground according to the authorised heritage discourse.

Our study reaches 40 metro stations belonging to 10 different metro lines crossing 12 heritage listed areas (Table 1). Significantly, the first heritage listed areas to be served by metro infrastructures were People's Square, site of the city government, and Hengshan Road-Fuxing
Road (abb. Hengfu), which corresponds to the former French Concession of the city: both were reached by Line 1 in 1995. At the time the heritage area listings were passed in 2003, only seven of the 12 listed areas were served by metro stations. Progressively, the development of metro infrastructure reached all heritage listed areas, with Longhua Road, included on Line 11 in 2013, being the last to be served (Fig. 1).

An analysis of this distribution shows that listed areas are unequally served by metro lines and stations. Even if the purpose of this paper is not to focus on the reasons station locations are selected, as this relates to technical criteria beyond the scope of this research, it is important to point out that the Hengfu area, which is the most extensive are in the city, is served by five lines, with 12 metro stations either within the area or within its limits. By contrast, other highly representative central heritage areas such as Waitan (where the Bund promenade and the old Central Business District of the city stand) or Laochengxiang (which is the original urban core of Shanghai) are served by only two and three stations, respectively, each located not within the areas but within their limits.

Our qualitative analysis focuses on two main aspects: first, the integration of the emerging elements of metro stations in the historic context through design or material means, and second, the narratives conveyed by the design of underground facilities (Table 2).

\subsection{Emerging elements: the first contextual response}

Design requirements in heritage areas vary greatly depending on the position of metro elements, either underground or above ground. Underground elements are the prerogative of the Shanghai Shentong Metro Group, which runs operations of the metro infrastructure. Elements above ground, despite being planned and designed by the same company, are, at least theoretically, subject to the aesthetic, volume and material regulations that apply for area protection according to the Regulations of Shanghai Municipality on the Protection of the Areas with Historical Cultural Features and the Excellent Historical Buildings (2002).

Nevertheless, our analysis shows that the regulations focus exclusively on the aesthetic appearance of listed areas and listed buildings but do not establish any specific determinations for the cases where both interact with the metro infrastructure. Articles 16 and 17 of the Regulations offer brief provisions for the case of road construction, with no reference to other transportation infrastructure. Article 20 establishes instructions about advertisements, without further provisions for the aesthetic integration of metro entrances. Only article 24 establishes some reference for the design of new structures 
Table 1 The 12 heritage listed areas and the stations included in this study

ZONE

ZONE 2: SHANYIN ROAD

ZONE 3: TILANQIAO

ZONE 4: WAITAN

ZONE 5: LAOCHENGXIANG

ZONE 6: PEOPLE'S SQUARE

ZONE 7: Weat NANJING ROAD

ZONE 8: HENGSHAN ROAD - FUXING ROAD (HENGFU)

ZONE 9: YUYUAN ROAD

ZONE 10: XINHUA ROAD

ZONE 11: HONGQIAO ROAD

ZONE 12: LONGHUA ROAD

LINE

10

8

3

10

4

10

2

10

9

$1,2,8$

2

7

1

10

7

9

13

2

11

3,4

10,11

10

11,12

\section{STATION}

DATE

Guoquan Road

Wujiaochang

Jiangwan Stadium

Nenjiang Road

Xiangyin Road

Dongbaoxing Road

Hongkou Fooball Stadium

Hailun Road

Dalian Road

Yangshupu Road

Tilanqiao

Tiantong Road

East Nanjing Road

East Nanjing Road

2010

2009

2000

2010

2005

2010

1999

Yuyuan Road

2010

Laoximen

2009

Xiaonanmen

1995 (Line 1)

1999 (Line 2)

2009 (Line 8)

1999

West Nanjing Road

Jing'an Temple

Changning Road

Jing'an Temple

2009

South Huangpi Road

South Shaanxi Road

Changshu Road

Hengshan Road

Xujiahui

Xintiandi

South Shaanxi Road

Shanghai Library

Changshu Road

Zhaojiabang Road

Zhaojiabang Road

Jiashan Road

Dapuqiao

Madang Road

Madang Road

Middle Huaihai Road

2009 (Line 9) 2010 (Line 13)

Jiangsu Road

Zhongshan Park

1999

Jiangsu Road

2013

Zhongshan Park

Jiao Tong University

Hongqiao Airport T1

Shanghai Zoo

Longxi Road

Shuicheng Road

Yili Road

Longhua Road 


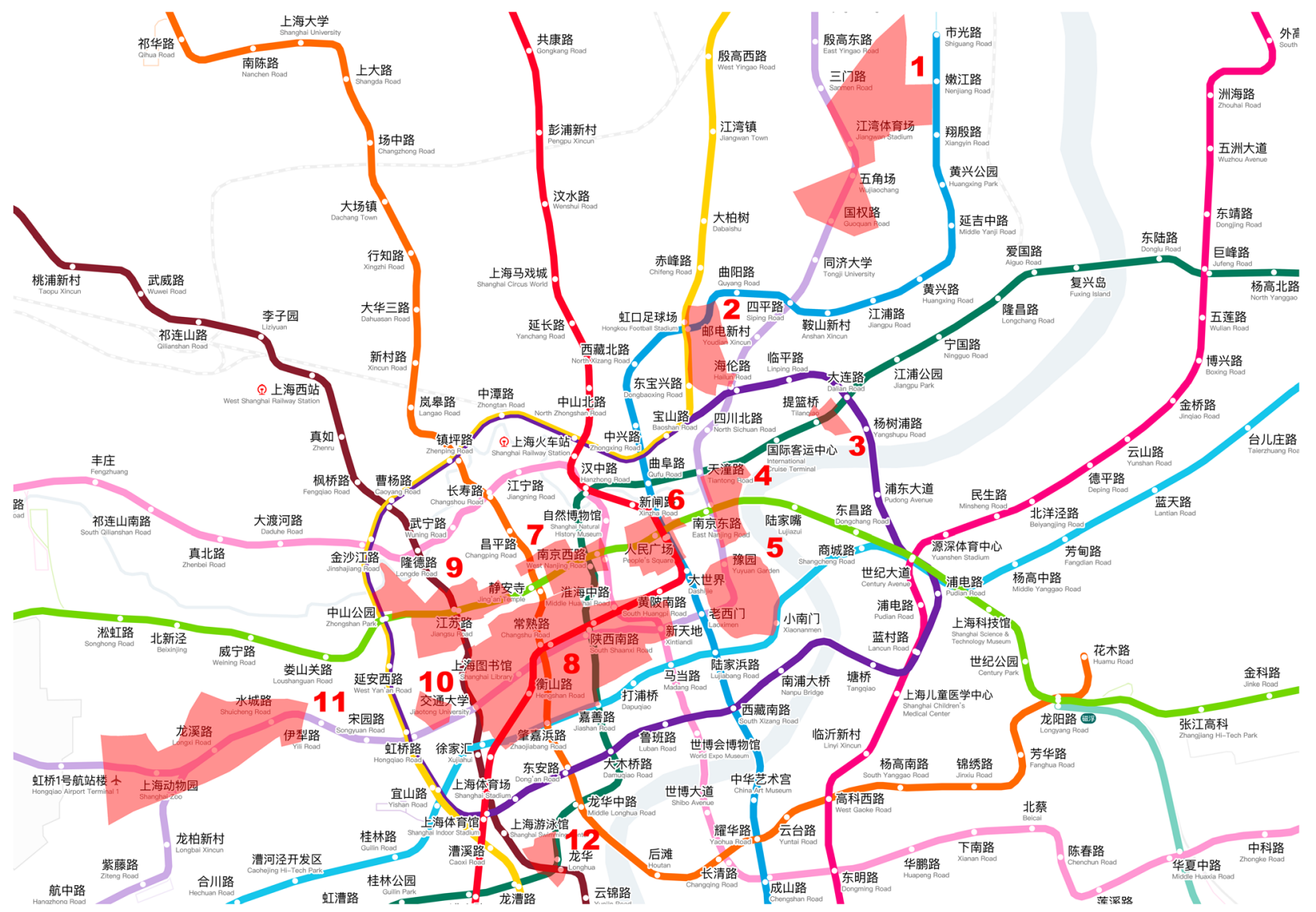

Fig. 1 Superposition of the Shanghai metro network and the location of the 12 cultural and historical listed areas of Shanghai. Legend: (1) Jiangwan; (2) Shanyin Road; (3) Tilanqiao; (4) Waitan; (5) Laochengxiang; (6) People's Square; (7) West Nanjing Road; (8) Hengshan Road - Fuxing Road (Hengfu); (9) Yuyuan Road; (10) Xinhua Road; (11) Hongqiao Road; (12) Longhua. (Source: the author)

in the vicinity of listed buildings within heritage areas that could also apply to metro entrances.

Fieldwork shows that the design of emerging elements haphazardly attempts contextualisation or harmonisation with the environment (Table 2). Most of them follow standard aesthetics, and their position, volume and materials establish a strong contrast with the surrounding areas. Non-freestanding station entrances are integrated in the overall design of buildings, as with Jing'an Metro Station, embedded in the wall of Jing'an Temple, and West Nanjing Road, which is concealed in the redeveloped lilongs along North Maoming Road (Figs. 2 and 3). Only one station, Jiao Tong University in lines 10 and 11, shows an attempt at contextualisation through a material analogy with the neighbouring brick structure of the listed Houston Court apartment building in the Hengfu area (Fig. 4), whereas the new entrance to West Nanjing Road Station in Shimen Road was artistically customised but lacks any aesthetic connection with the environment (Fig. 5).

\subsection{Underground elements: the development of an analogous heritage city}

The analysis of underground elements, namely, metro stations and platforms, shows a richer variety of manifestations of culture and sense of place (Table 2). These elements are classified into three main groups: architecture (building shapes, materials, fittings and characteristic features); applied arts (sculptures, murals, pictures and engravings); and permanent exhibition displays.

A chronological analysis of their incorporation helps to understand the evolving production of narratives in relationship with the appreciation of urban heritage above ground. The first metro lines developed in the 1990s; lines 1,2 , and 3 either incorporated elements of applied arts or no elements at all. Consisting mainly of paintings and engravings, these elements of applied arts mainly narrate Chinese traditional culture. They seem to offer a cultural complement to the modern infrastructure, even though they do not reflect the values or attributes of the urban heritage areas that the stations cater to. 
Table 2 Main cultural features incorporated to metro stations

\begin{tabular}{|c|c|c|c|c|}
\hline YEAR & STATION & FEATURES & LINE & HERITAGE AREA \\
\hline \multirow[t]{6}{*}{1995} & South Huangpi Road & Remnants of calligraphy and disconnected classic decorative elements & \multirow[t]{5}{*}{1} & \multirow{5}{*}{$\begin{array}{l}\text { ZONE 8: HENG SHAN ROAD - } \\
\text { FUXING ROAD }\end{array}$} \\
\hline & South Shaanxi Road & $\begin{array}{l}\text { Display window of Shanghai Oil Painting and Sculpture institute, } \\
\text { with pictures of people in old settings } \\
\text { Classic painting of clouds and mountains }\end{array}$ & & \\
\hline & Changsu Road & No specific features & & \\
\hline & Hengshan Road & No specific features & & \\
\hline & Xujiahui & $\begin{array}{l}\text { Carved Chinese calligraphy of 'Shanghai Metro Art Corridor', with } \\
\text { original artworks covered by billboards }\end{array}$ & & \\
\hline & People's Square & Murals & 1 & ZONE 6: PEOPLE'S SQUARE \\
\hline \multirow[t]{6}{*}{1999} & East Nanjing Road & No specific features & 2 & ZONE 4: WAITAN \\
\hline & People's Square (extension) & No specific features & 2 & ZONE 6: PEOPLE'S SQUARE \\
\hline & West Nanjing Road & No specific features & \multirow[t]{2}{*}{2} & \multirow{2}{*}{$\begin{array}{l}\text { ZONE 7: WEST NANJING } \\
\text { ROAD }\end{array}$} \\
\hline & Jing'an Temple & $\begin{array}{l}\text { Marble engravings 'Eight Scenes of Jing'an', currently covered by } \\
\text { vending machines and billboards. } \\
\text { Exit } 1 \text { integrated in Jing'an Temple }\end{array}$ & & \\
\hline & Jiangsu Road & No specific features & \multirow[t]{2}{*}{2} & \multirow[t]{2}{*}{ ZONE 9: YUYUAN ROAD } \\
\hline & Zhongshan Park & No specific features & & \\
\hline \multirow[t]{3}{*}{2000} & Dongbaoxing Road & No specific features & \multirow[t]{2}{*}{3} & \multirow[t]{2}{*}{ ZONE 2: SHANYIN ROAD } \\
\hline & Hongkou Fooball Stadium & $\begin{array}{l}\text { Archaic mural wall 'Emperors hunting deer in the Central Plain' } \\
\text { 'Publicity corridor' featuring neighbouring Luxun Park }\end{array}$ & & \\
\hline & Zhongshan Park (extension) & No specific features & 3 & ZONE 9: YUYUAN ROAD \\
\hline \multirow[t]{3}{*}{2005} & Dalian Road & $\begin{array}{l}\text { Cultural wall with metal artworks: bicycles } \\
\text { Main entrance to the National Anthem Museum: shikumen-inspired } \\
\text { design } \\
\text { Use of shikumen brick as cover material }\end{array}$ & \multirow[t]{2}{*}{4} & \multirow[t]{2}{*}{ ZONE 3: TILANQIAO } \\
\hline & Yangshupu Road & $\begin{array}{l}\text { Cultural wall with metal artworks: rickshaws } \\
\text { Ink paintings exhibition: 'Master Works Entering the Subway Tour' }\end{array}$ & & \\
\hline & Zhongshan Park (extension 2) & No specific features & 4 & ZONE 9: YUYUAN ROAD \\
\hline \multirow[t]{12}{*}{2009} & People's Square (extension 2) & 'Shanghai 1930s street' in connection to Shanghai Planning Museum & 8 & ZONE 6: PEOPLE'S SQUARE \\
\hline & Nenjiang Road & No specific features & \multirow{2}{*}{$\begin{array}{l}8 \\
8\end{array}$} & ZONE 1: JIANGWAN \\
\hline & Xiangjin Road & No specific features & & ZONE 1: JIANGWAN \\
\hline & Changning Road & No specific features & \multirow[t]{2}{*}{7} & \multirow{2}{*}{$\begin{array}{l}\text { ZONE 7: WEST NANJING } \\
\text { ROAD }\end{array}$} \\
\hline & Jing'an Temple (extension) & No specific features & & \\
\hline & Changsu Road & No specific features & \multirow[t]{2}{*}{7} & \multirow{2}{*}{$\begin{array}{l}\text { ZONE 8: HENG SHAN ROAD - } \\
\text { FUXING ROAD }\end{array}$} \\
\hline & Zhaojiabang Road & No specific features & & \\
\hline & Zhaojiabang Road & No specific features & \multirow[t]{4}{*}{9} & \multirow{4}{*}{$\begin{array}{l}\text { ZONE 8: HENG SHAN ROAD - } \\
\text { FUXING ROAD }\end{array}$} \\
\hline & Jiashan Road & $\begin{array}{l}\text { Shikumen features in the station ceiling } \\
\text { Mural of Shanghai skyline (sticker) }\end{array}$ & & \\
\hline & Dapuqiao & No specific features & & \\
\hline & Madang Road & Murals of shikumen (stone and stickers) & & \\
\hline & Xiaonanmen & No specific features & 9 & ZONE 5: LAOCHENGXIANG \\
\hline \multirow[t]{5}{*}{2010} & Guoquan Road & No specific features & \multirow[t]{3}{*}{10} & \multirow[t]{3}{*}{ ZONE 1: JIANGWAN } \\
\hline & Wujiaochang & No specific features & & \\
\hline & Jiangwan Stadium & $\begin{array}{l}\text { Watercolour exhibition } \\
\text { Commercial gallery, shikumen style } \\
\text { Entrance } 1 \text { in axial relationship with Jiangwan Stadium }\end{array}$ & & \\
\hline & East Nanjing Road & $\begin{array}{l}\text { Mural decoration featuring Nanjing Road skyline, rickshaws and } \\
\text { qipao (sticker). }\end{array}$ & 10 & ZONE 4: WAITAN \\
\hline & Yuyuan Garden & Wall painting 'Wind of Rhyme', featuring traditional business in & 10 & ZONE 5: LAOCHENGXIANG \\
\hline
\end{tabular}


Table 2 Main cultural features incorporated to metro stations (Continued)

\begin{tabular}{|c|c|c|c|c|}
\hline YEAR & STATION & FEATURES & LINE & HERITAGE AREA \\
\hline & & $\begin{array}{l}\text { Laoximen } \\
\text { Chinese decorative patterns in columns (sticker) }\end{array}$ & & \\
\hline & Laoximen & No specific features & & \\
\hline & Xintiandi & $\begin{array}{l}\text { Brick cover, shikumen style } \\
\text { Brick patterns in flooring } \\
\text { Shikumen mural with AV display } \\
\text { Signage in cooper, 1930s style } \\
\text { Posters } \\
\text { Light fittings, 1930s style } \\
\text { Exhibition display: origins of CCP }\end{array}$ & 10 & $\begin{array}{l}\text { ZONE 8: HENG SHAN ROAD - } \\
\text { FUXING ROAD }\end{array}$ \\
\hline & South Shaanxi Road & No specific features & & \\
\hline & Shanghai Library & Calligraphy wall & & \\
\hline & Jiao Tong University & $\begin{array}{l}\text { Entrance integration to Qian Xuesen Library (materials) } \\
\text { Entrance integration to Dengyun Apartment (materials) } \\
\text { Allegoric mural of Jiao Tong University }\end{array}$ & 10 & ZONE 10: XINHUA ROAD \\
\hline & Hongqiao Airport T1 & No specific features & 10 & ZONE 11: HONGQIAO ROAD \\
\hline & Longxi Road & No specific features & & \\
\hline & Shuicheng Road & No specific features & & \\
\hline & Yili Road & No specific features & & \\
\hline & Madang Road (extension) & No specific features & 13 & $\begin{array}{l}\text { ZONE 8: HENG SHAN ROAD - } \\
\text { FUXING ROAD }\end{array}$ \\
\hline \multirow[t]{3}{*}{2013} & Jiangsu Road (extension) & No specific features & 11 & ZONE 9: YUYUAN ROAD \\
\hline & $\begin{array}{l}\text { Jiao Tong University } \\
\text { (extension) }\end{array}$ & No specific features & 11 & ZONE 10: XINHUA ROAD \\
\hline & Longhua Road & $\begin{array}{l}\text { Calligraphy reliefs } \\
\text { Lotus shape reliefs } \\
\text { Ceiling design: temple architecture shape and colours } \\
\text { Mural with Buddha motives }\end{array}$ & 11 & ZONE 12: LONGHUA ROAD \\
\hline \multirow[t]{4}{*}{2015} & Longhua Road & Ceiling design: temple architecture shape and colours & 12 & ZONE 12: LONGHUA ROAD \\
\hline & Middle Huaihai Road & $\begin{array}{l}\text { Brick cover, shikumen style } \\
\text { Brick patterns in flooring } \\
\text { Plaques in cooper with station name, 1930s style }\end{array}$ & 13 & $\begin{array}{l}\text { ZONE 8: HENG SHAN ROAD - } \\
\text { FUXING ROAD }\end{array}$ \\
\hline & West Nanjing Road & Entrance pavilion covered by vegetation & 12 & \multirow{2}{*}{$\begin{array}{l}\text { ZONE 7: WEST NANJING } \\
\text { ROAD }\end{array}$} \\
\hline & West Nanjing Road & Entrance integration to redeveloped Jianyeli shikumen & 13 & \\
\hline
\end{tabular}

This tendency changed after the listings in 2003: new stations incorporated mainly architectural elements and permanent exhibitions, outnumbering stations that incorporated applied arts. Since that time, there has been a steady use of metro stations and platforms as holders of the local culture represented by the heritage listed areas. We argue that this reflects the turn towards the appreciation of Shanghai's built culture fostered by the 2010 Shanghai Expo, which boosted the completion of the metro network and the production of an image of Shanghai as a global city. We also contend that this image rests on three different narratives that reflect official heritage discourses in the city:

- Chinese traditional culture is mainly represented by the applied arts, incorporating reproductions of traditional paintings and calligraphy. Inaugural line 1 features murals and calligraphy engravings in the key central areas of People's Square and Hengfu (Fig. 6), whereas the more recent line 10 incorporates calligraphy samples in the station, which serves the new Shanghai Library in Hengfu. More recent lines incorporate representations of daily life, in what we contend is an acknowledgement of the weight of intangible heritage in urban images, like the iconic representations of bicycles and rickshaws in line 4 through the Tilanqiao listed area. Interestingly, more recent representations include religious motifs, such as the Buddhist iconography displayed in the metro station of line 11 in Longhua Road (Fig. 7). 


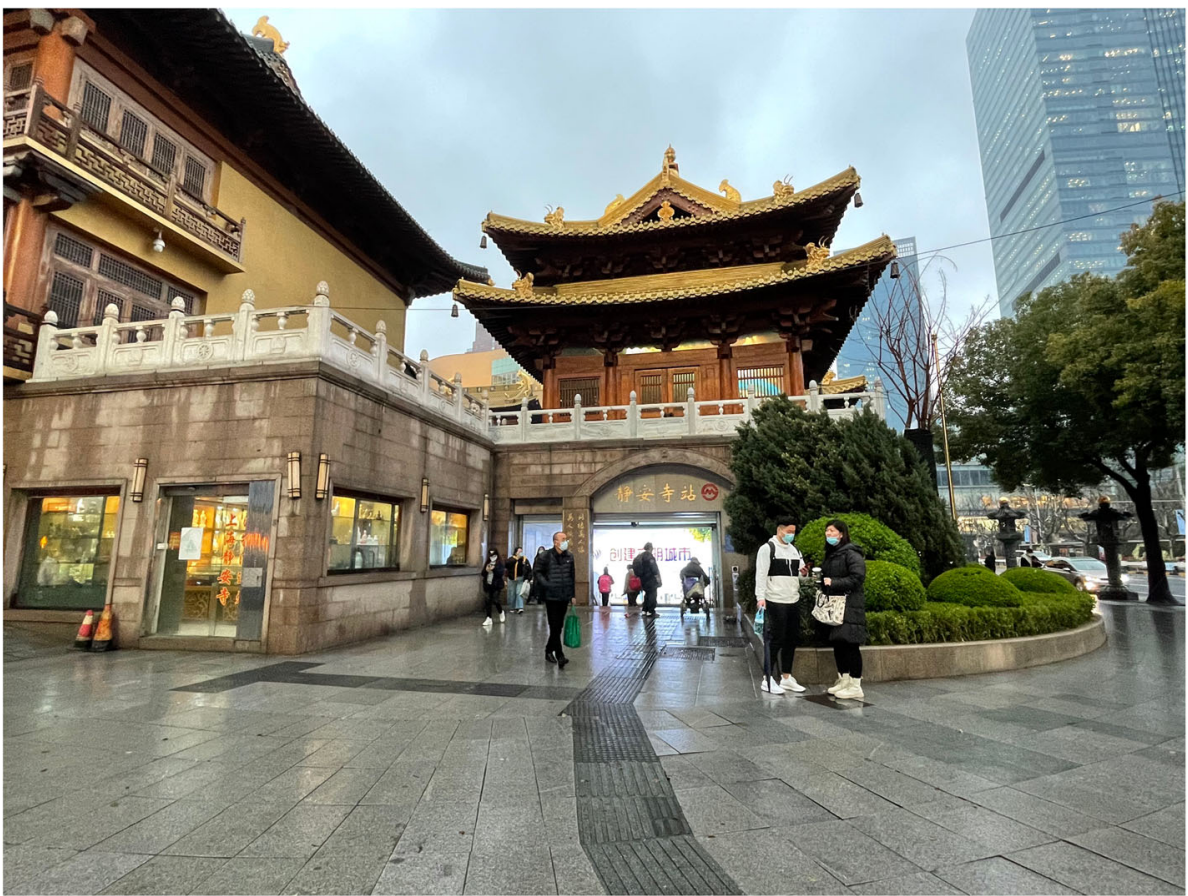

Fig. 2 Entrance to Jing'an Metro Station (metro line 2). (Source: the author)

- Shanghai haipai ${ }^{3}$ local culture is broadly represented by the architectural elements of the Shanghai shikumen, ${ }^{4}$ which since 2005 have appeared recurrently in five of the 12 listed areas: Tilanqiao, People's Square, Hengfu, Jiangwan Stadium and West Nanjing Road. Architectural elements are featured at eight stations in total and refer mostly to the use of materials, conferring stations with characteristic grey and red brick surface colours, as well as with the shape and material of the stone gates of the shikumen (Fig. 8). The intangible culture of fashion is also featured in murals representing characteristic Shanghainese female attire, such as cheongsam or qipao, particular in the East Nanjing Road station, which serves the Waitan area, and the West Nanjing Road Station, which serves to the West Nanjing Road area. (Fig. 9).

- History of Communism is represented by exhibition displays, which appear in two of the 12 listed areas: Tilanqiao and Hengfu. The exhibitions, located at Tilanqiao (line 4) and Xintiandi (line 10) stations, act

\footnotetext{
${ }^{3}$ Meaning, literally, the 'Shanghai style' in Chinese, haipai is considered an expression of Shanghai's cosmopolitanism resulting from the Westernization of Chinese culture.

${ }^{4}$ Typically found in high-density neighbourhoods known as lilong, the shikumen is Shanghai's traditional vernacular residential type. It combines Chinese vernacular and modern Western architectural housing styles. The name shikumen originates from the monumental stonecarved gate leading to the south side of a courtyard, around which the main of the rooms are arranged (González Martínez 2020).
}

as reminders of two important cultural sites, the National Anthem Gallery (Fig. 10) and the Site of the First National Congress of the Communist Party of China (CPC) (Fig. 11), respectively, located above ground. The special significance of the CPC site is also incorporated through a highly specific architectural element: the fully ornamented, brick-caved shikumen gate of 76 Xingye Road, whose shape has become an icon of the origins of the Communist Party of China in Shanghai and across the country (Fig. 12) (Table 3).

Considering that the production of heritage relies not only on the enhancement of significant narratives and elements but also on the omission of others, it is important to highlight that none of the studied elements refer to archaeological findings of any kind. At least theoretically, these findings could have been significant at the stations around the Laochengxiang listed area, which corresponds to the foundational site of the city: Yuyuan Road, Laoximen and Xiaonanmen. Our study also found no correspondence between the core narrative that founded the listing of the Tilanqiao area (the painful memory of the Jewish exile during the 1930s and 1940s, locally interpreted as proof of Shanghai's openness) and the narratives displayed on site, which focus on scenes from everyday life. The same selective choice appears in Longhua Road station, which privileges the featuring of Buddhist architecture and decorations instead of reflecting on the history of the Longhua Martyrs that underlies the memorial and burial site above ground, next to the temple. 


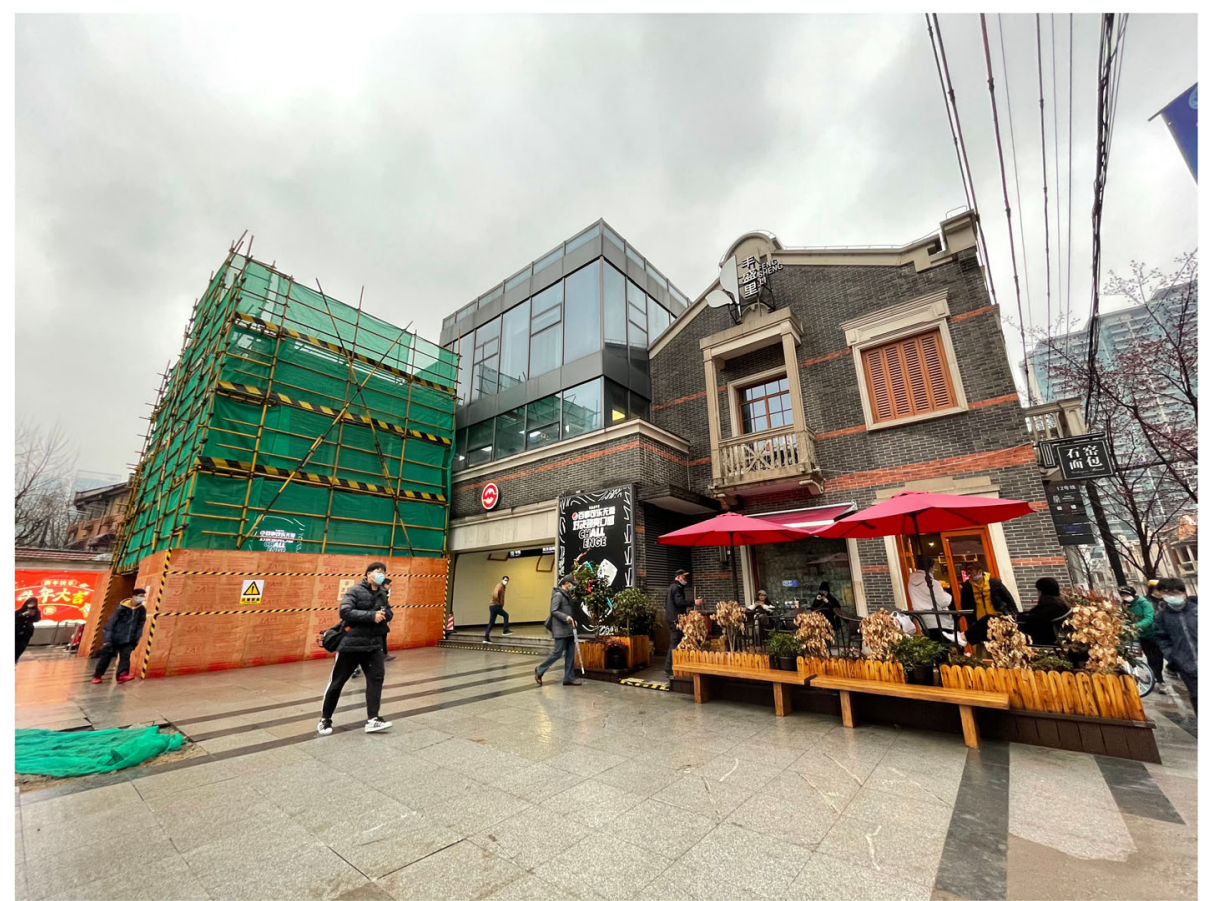

Fig. 3 Entrance to West Nanjing Road Metro Station (metro line 12). (Source: the author)

Finally, together with underrepresented topics, we need to highlight underrepresented areas in the metro. Significantly, stations in three listed areas, Yuyuan Road, Xinhua Road and Hongqiao, located west of the downtown, lack any particular cultural features and appear as 'heritage blanks' in underground representations. Particularly, again, the heritage narratives and elements neglect two central areas of key importance in the history of the city: Waitan, which merely incorporates a brief mention of the urban landscape of East Nanjing Road and the culture of qipao, and most importantly, Laochengxiang, or

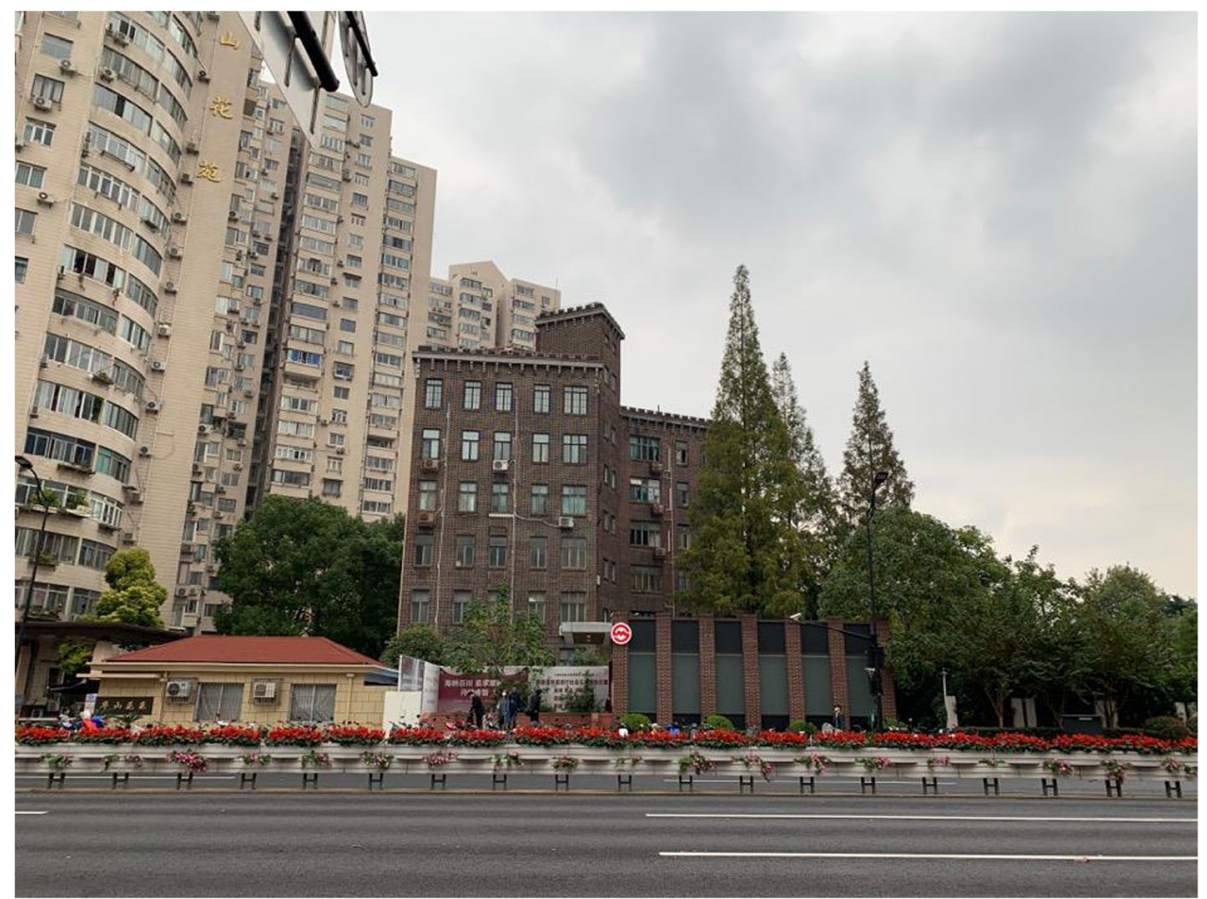

Fig. 4 Entrance to Jiao Tong University Metro Station (metro lines 10-11) with Houston Court apartments in the background. (Source: the author) 


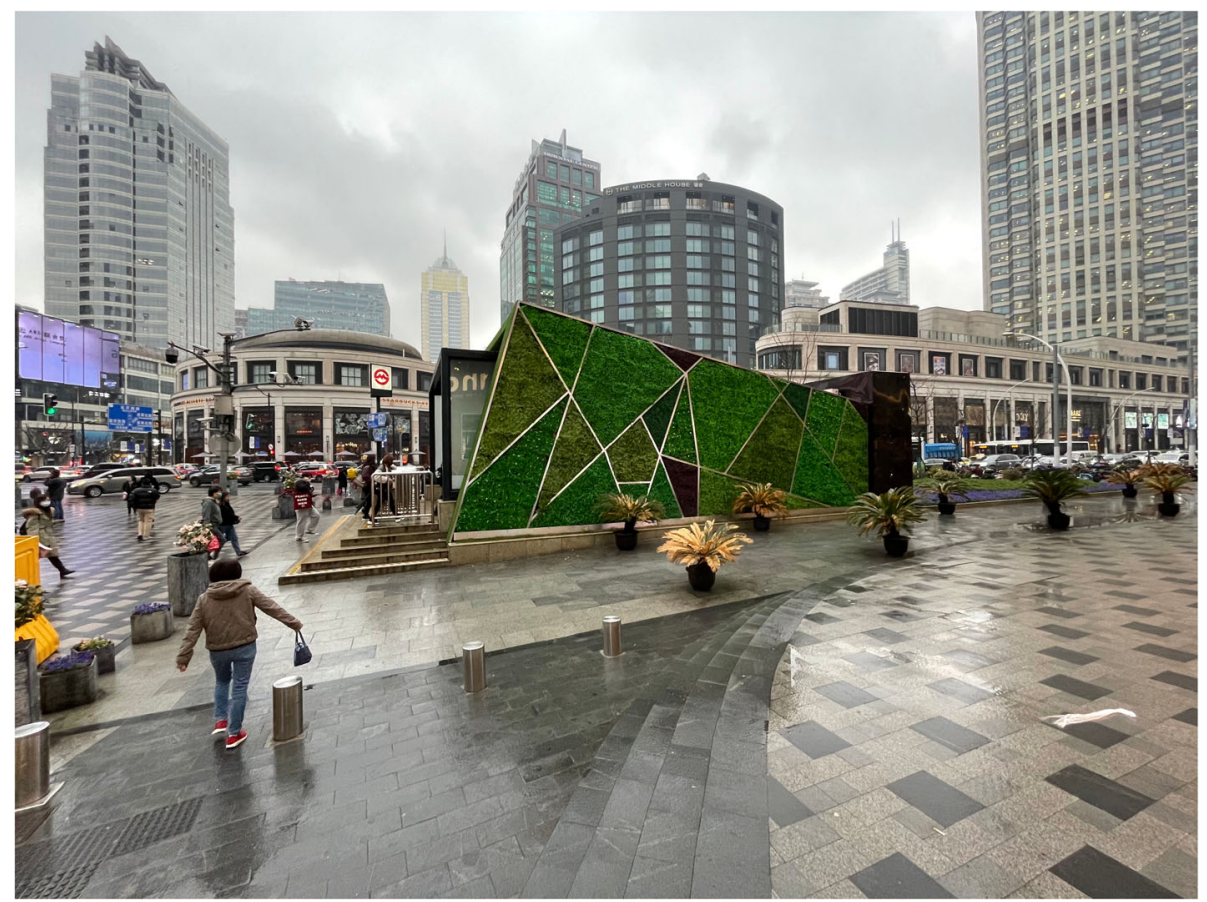

Fig. 5 Entrance to West Nanjing Road Metro Station (metro line 11). (Source: the author)

the old city centre of Shanghai, which only incorporates one mural depicting everyday life in Yuyuan Garden Station, while its history fails to become part of the design in the other two stations (Laoximen and Xiaonanmen) that serve it.

\section{Discussion}

The discourse analysis of cultural features in the Shanghai Metro shows how its consideration is a powerful transmission channel, representative of the turn towards the production of new local historical narratives in China (Law

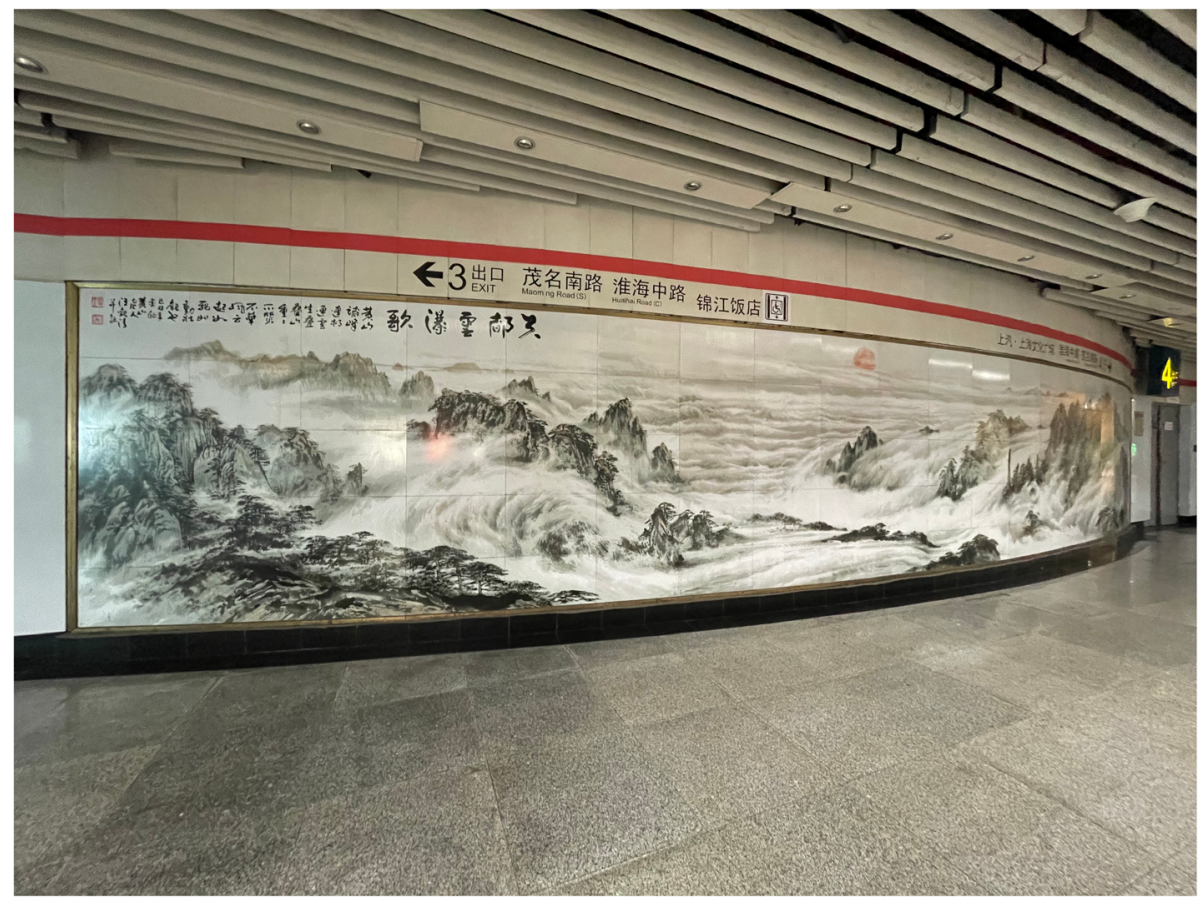

Fig. 6 Mural in South Shaanxi Road Metro Station (line 1). (Source: the author) 


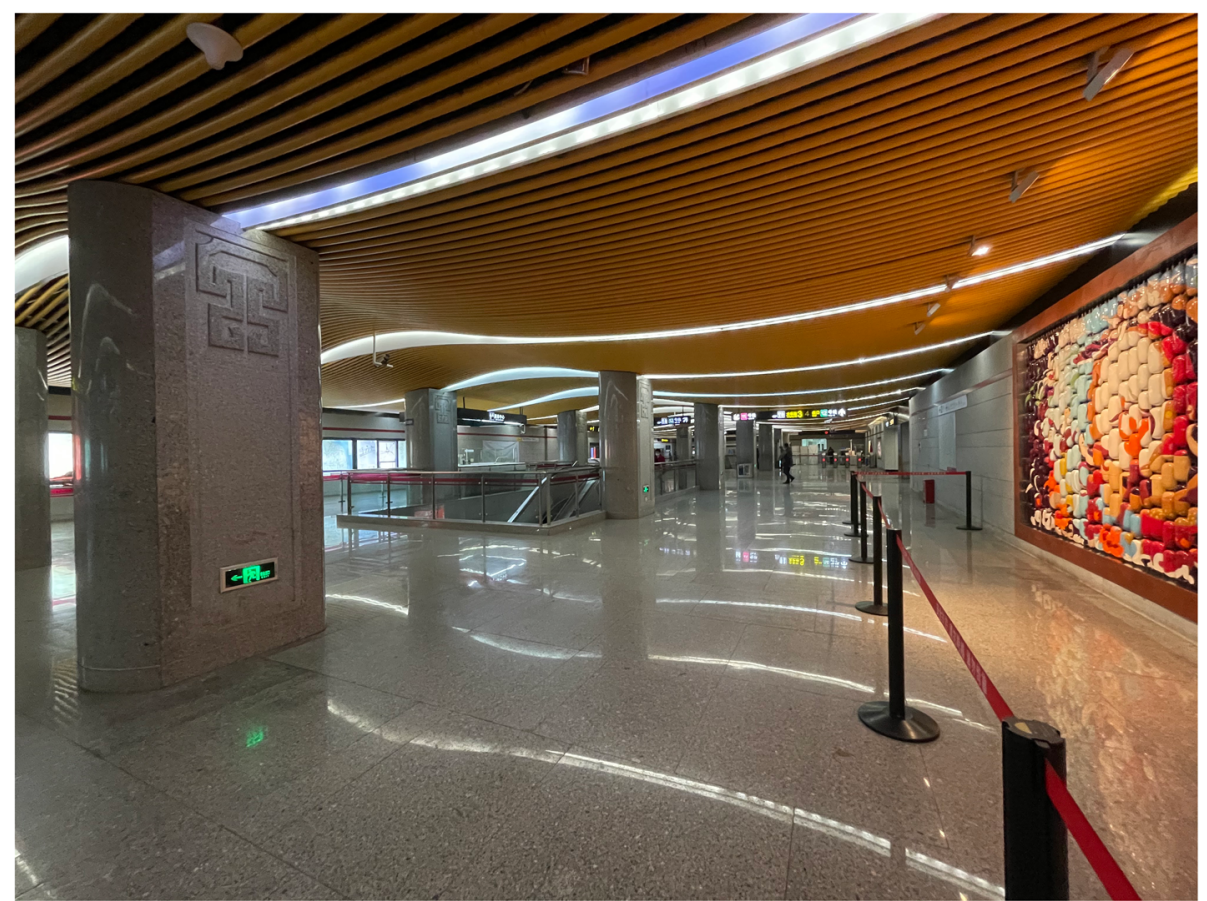

Fig. 7 Buddhist mural representation (right) and traditional design carvings in the stone cladding of pillars (left) at Longhua Road Metro Station (Line 11). (Source: the author)

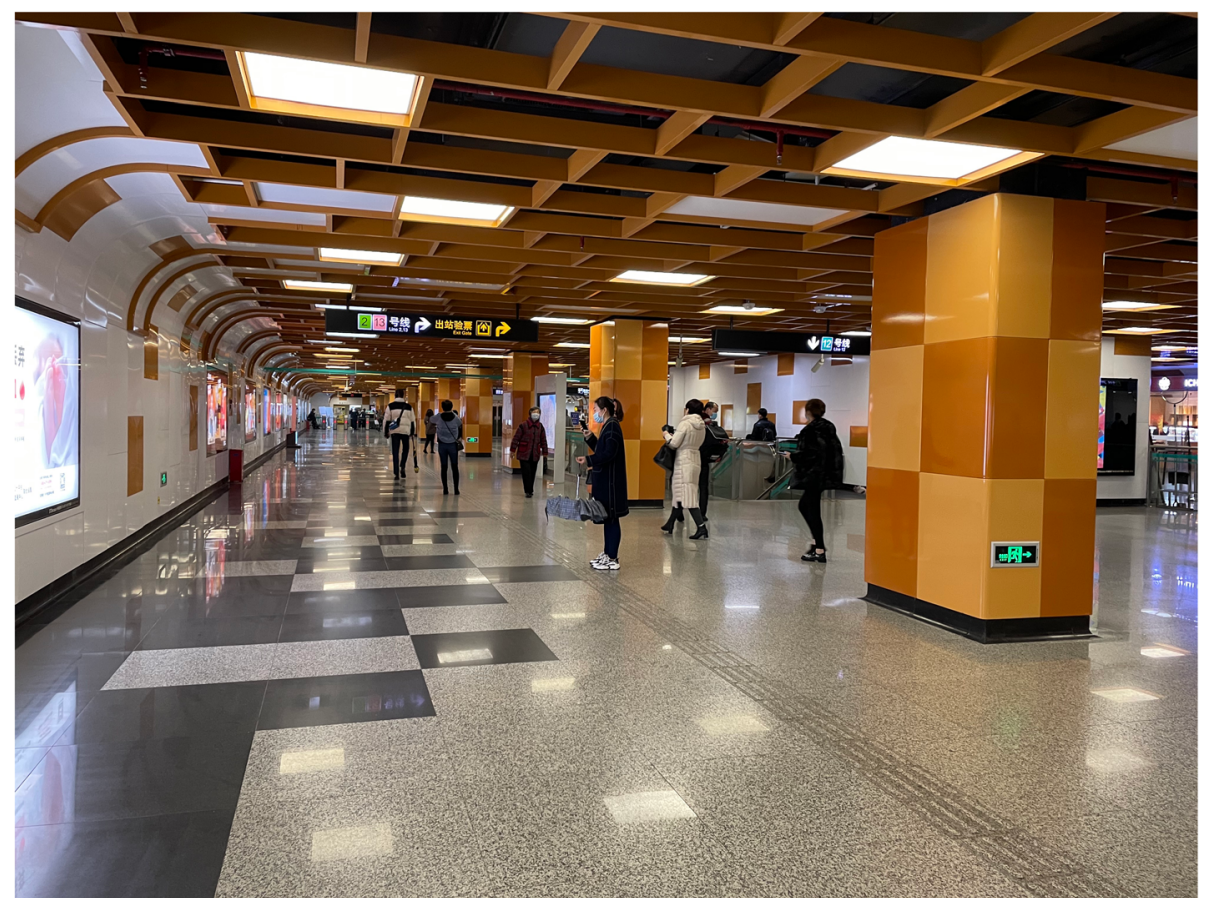

Fig. 8 The 'reverberance' of the stone lintels of shikumen gates in the curved transition between walls and ceilings in West Nanjing Road Station. (Source: the author) 


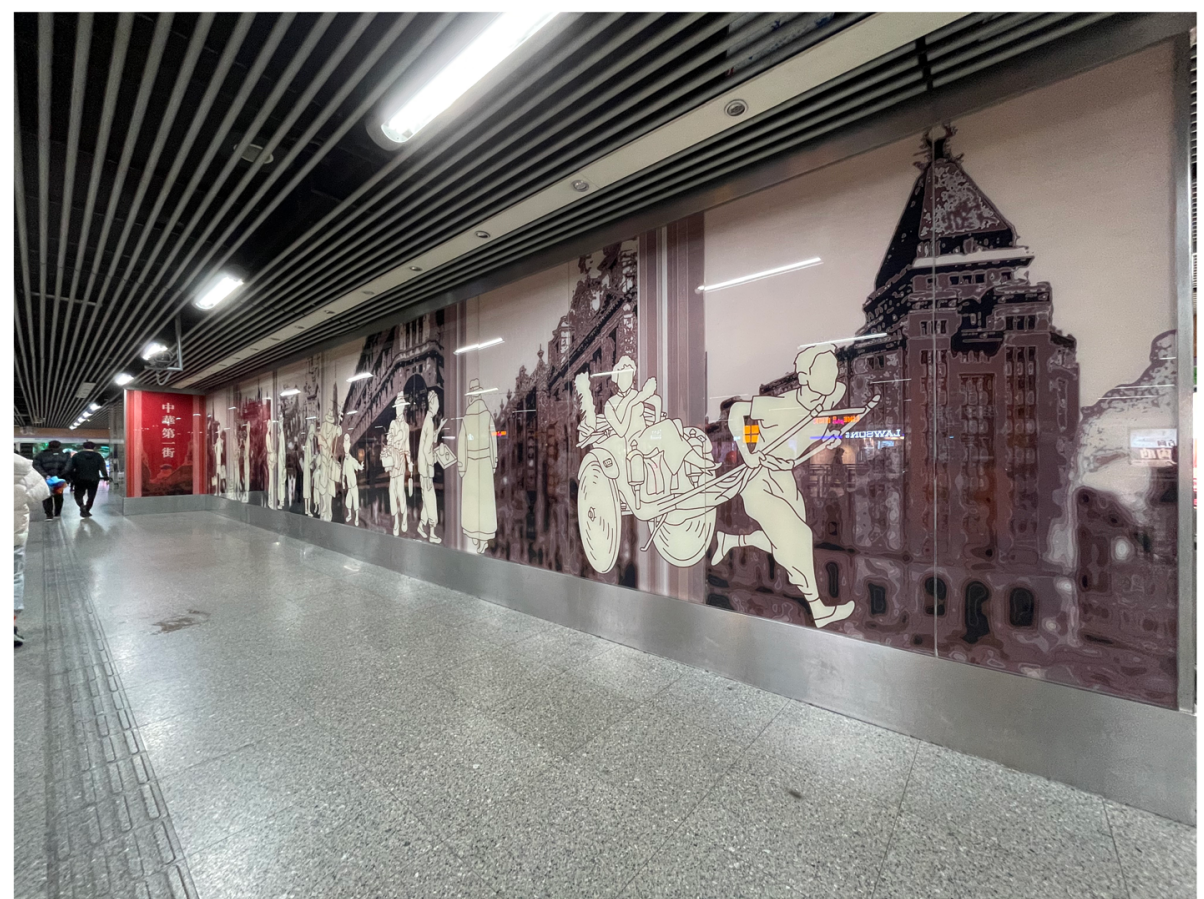

Fig. 9 Representation of street activity at East Nanjing Road Station (line 10). (Source: the author)

2012; Law and Qin 2017; Zhu 2019; González Martínez 2020). The cultural strategies used in metro stations lead to a highly intentional presentation of the heritage above ground with the purpose of supporting official discourses of legitimacy, solidarity and harmony (Zhu 2019; Zhu and Maags 2020). As we argue, the display of cultural-related elements needs to be straightforward and highly pervasive in a context such as the underground, where the gaze of the public is distracted by speed and the flow of information from signs, advertisements and smartphones.

The simplified presentation of heritage enables its authentication according to the major official narratives of

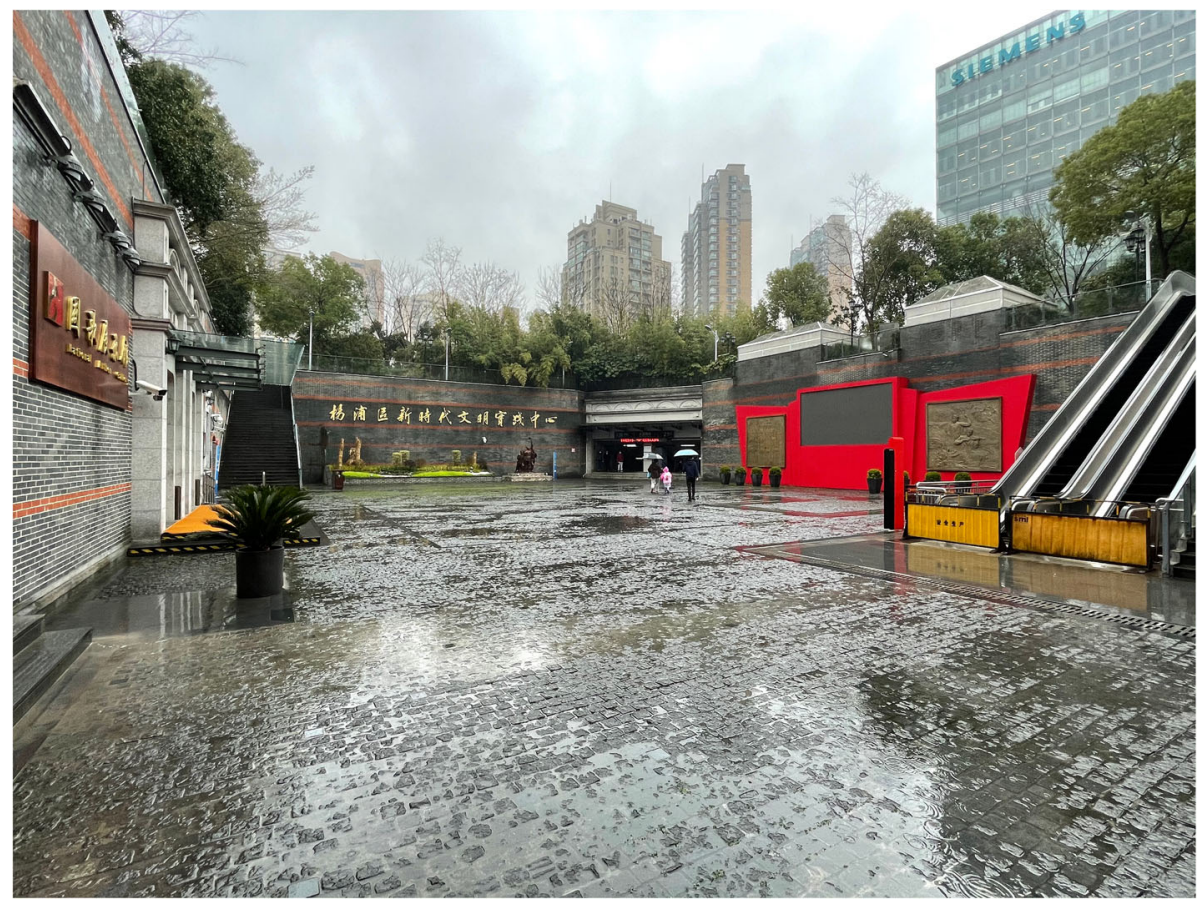

Fig. 10 Entrance to the National Anthem Gallery (left), in the sunken plaza of Tilanqiao Station (line 4). (Source: the author) 


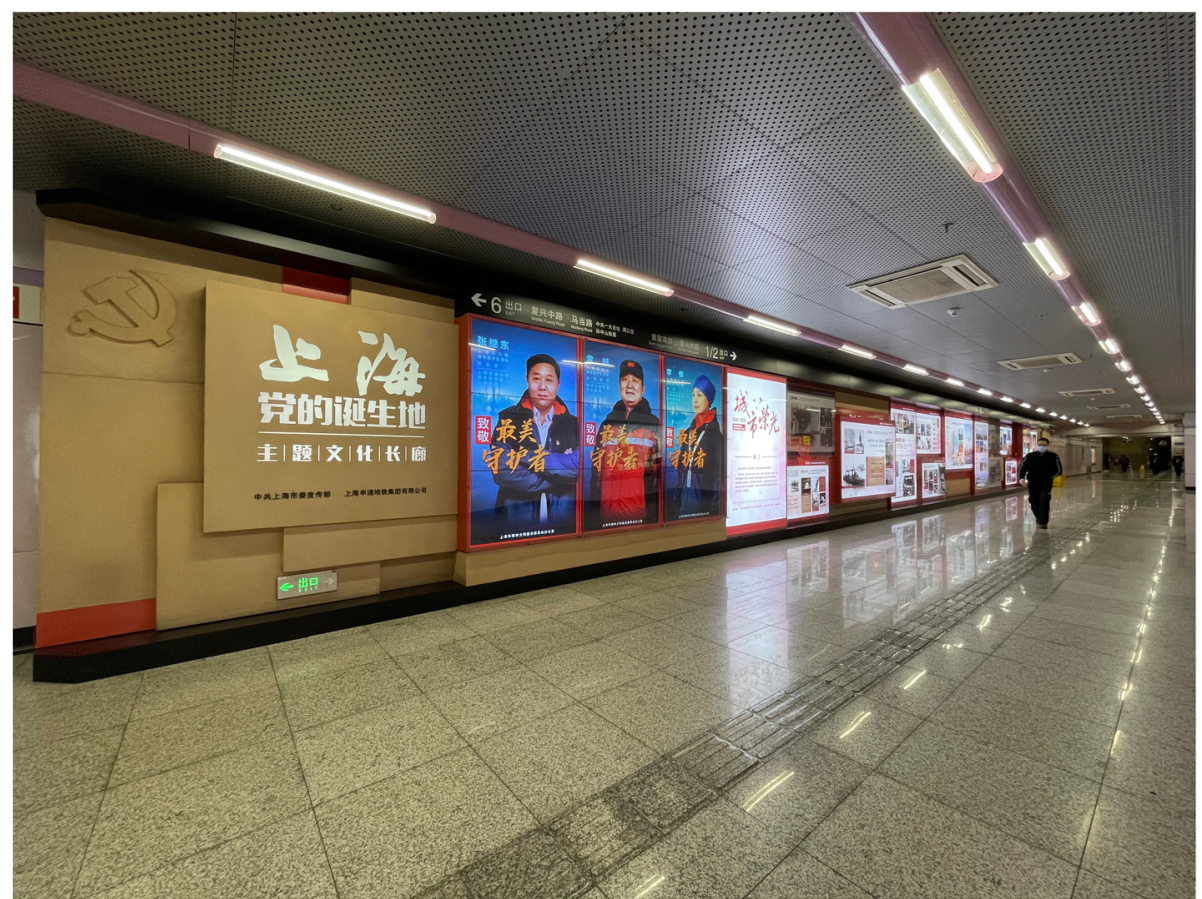

Fig. 11 Exhibition on the founding of the Communist Party of China in Xintiandi Station (lines 10-11). (Source: the author)

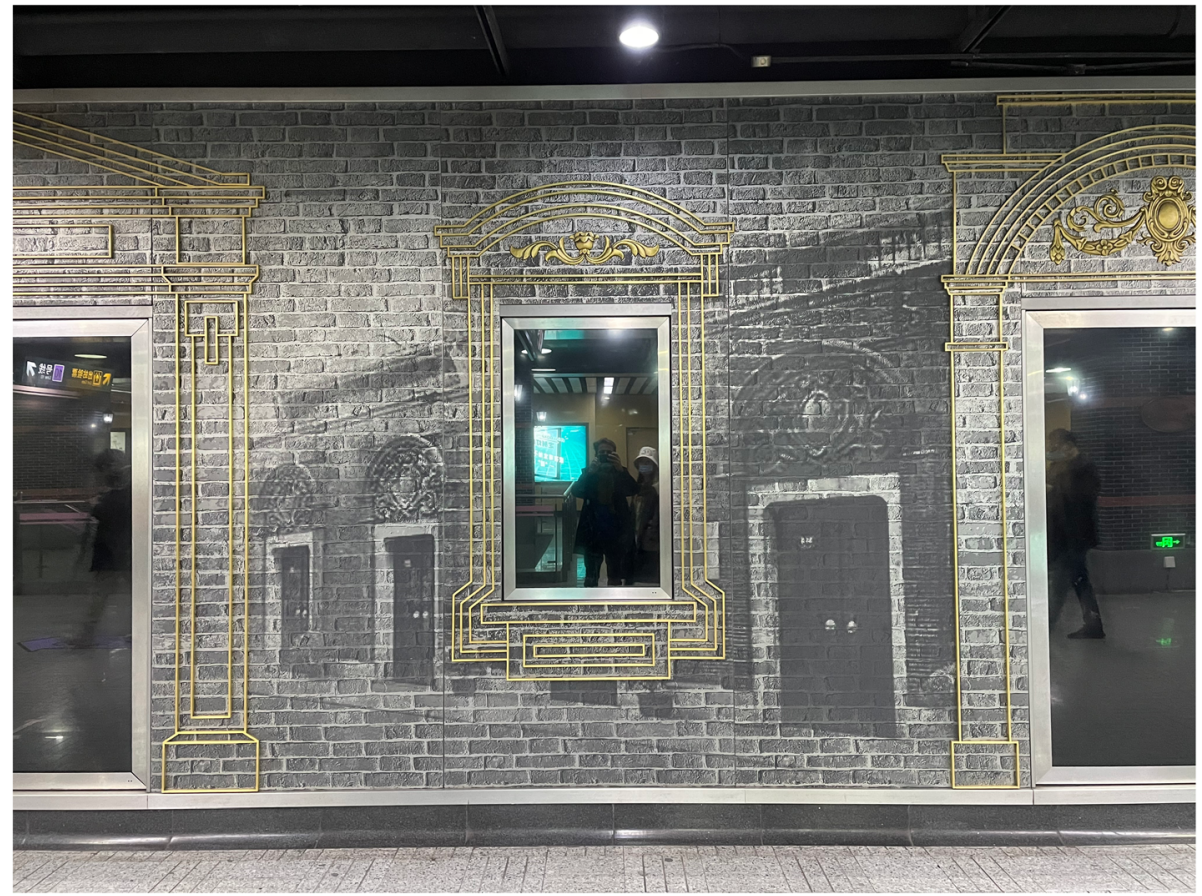

Fig. 12 Representation of the shikumen gate of 76 Xingye Road, Site of the First National Congress of the Communist Party of China. (Source: the author) 
Table 3 Main heritage narratives developed in the Shanghai Metro

\begin{tabular}{lll}
\hline NARRATIVE & SUPPORTING HERITAGE ITEM & HERITAGE LISTED AREAS \\
\hline Traditional Culture & Murals & ZONE 1: JIANGWAN \\
& & ZONE 2: SHANYIN ROAD \\
& & ZONE 5: LAOCHENGXIANG \\
& & ZONE 6: PEOPLE'S SQUARE \\
& ZONE 8: HENG SHAN ROAD - FUXING ROAD \\
& ZONE 12: LONGHUA ROAD \\
& Engravings & ZONE 7: WEST NANJING ROAD \\
& Calligraphy & ZONE 8: HENG SHAN ROAD - FUXING ROAD \\
& Religious motifs & ZONE 12: LONGHUA ROAD \\
& Traditional architecture & ZONE 12: LONGHUA ROAD \\
& Shikumen & ZONE 1: JIANGWAN \\
& ZONE 3: TILANQIAO \\
& ZONE 6: PEOPLE'S SQUARE \\
& ZONE 7: WEST NANJING ROAD \\
& ZONE 8: HENG SHAN ROAD - FUXING ROAD \\
& ZONE 4: WAITAN
\end{tabular}

an authorised heritage discourse. In this sense, the 'white canvas' offered by metro stations in Shanghai confirms the characterisation of urban infrastructures as 'black boxes' in the realm of specialists, be they transportation engineers or cultural planners. However, at the same time, this 'white canvas' enables the interpretation of phenomena occurring above ground and throughout the recent history of the city. For instance, our chronological analysis offers evidence of the historic departure of China's 'heritage fever' around the turn of the century (Ludwig and Walton 2020; Zhu and Maags 2020). The stark contrast between the cultural features represented in metro stations before and after the 2003 listings indicates a fully conscious use of metro stations as powerful conveyors of cultural messages that create the contemporary identity of the city.

Discourse analysis confirms how the museum-like orientation of the heritage content of the metro in the 1990s, featuring movable objects and artworks, was impervious to the mass demolition brought by the ' 365 Plan' promoted by the Shanghai Municipality during that decade. ${ }^{5}$ The 'parallel reality' produced by cultural features in metro stations experienced a shift in tendency after the city was awarded the organisation of the 2010 Expo in December 2002 and the creation of the 12 listed areas in 2003. In the framework of the massive urban changes that led to the Expo, of which the metro

\footnotetext{
${ }^{5}$ The name of the plan reflected the demolition of 365 ha of the historic city (Ren 2008).
}

system was a highlight, these features started to show an enhanced awareness of both the characteristics and the changes above ground. Our analysis shows how this happens both at the level of the detected 'inclusions' and that of 'omissions', which summarise the selective production of historical narratives akin to authorised heritage discourses (Smith 2006) and city branding strategies (Ashworth and Karavatzis 2011).

Referring to the selected inclusions, we argue that cultural features aim to reinforce official discourses on tradition, which become a governance asset. The examples of Moscow and Pyongyang clearly show how official narratives permeated the design of metro stations. What is novel in our case is that the messages conveyed in the metro are not only political but also refer to a wider social and cultural understanding of the city as a stage with a shifting, dynamic power balance. The registered evidence, particularly of the architectural shapes, building elements and materials of the Shanghai shikumen, shows a double-pronged approach, available for both global and domestic interpretation. On the one hand, they feature a clear expression of the cosmopolitan origins of this residential typology, where most of the Shanghainese population lived during the 19th and 20th centuries, therefore reinforcing the international connections of the city. On the other hand, the choice for the iconic gate of 76 Xingye Road enhances Shanghai's symbolic profile at a national level as the birthplace of Communism in China. Furthermore, taking, for instance, the Buddhist iconography of Longhua Road station, the selection of 
religious symbols is representative of a reinforced national coherence among diverse cultures and ethnic groups (Zhu and Maags 2020).

Together with the evidence of 'inclusions', our analysis shows an important connection between metro stations and the spaces of forgetfulness, as studied by Harrison (2013). Significantly, we argue that the 'omissions' in the Metro also contribute significantly to an overall discourse of developmentalism. This refers, for instance, to metro entrances above ground, which prompt immediate visual interaction between listed heritage areas and metro systems. In this sense, their location and aesthetics show an overall lack of attention. Apart from the cases where they are integrated into heritage assets, these elements appear generally careless about establishing any compositional or material dialogue with the surroundings, even if this should be deemed a cultural prerequisite of transit-oriented development. We could argue that in a highly volatile developmental environment, designers have abdicated from this responsibility because the urban context cannot be deemed a fixed, stable scenario.

Our research also refers to the lack of references to the archaeological heritage of the city, even if its significance may not compare to that of other cities in China such as Xi'an or Beijing. Even so and surprisingly, archaeology is still absent from the official narratives despite its potential relevance at a local level in areas such as Laochengxiang. We contend that this responds to the selective choice of historical periods and the privileging of Shanghai's cosmopolitan aura since 1843 (Law 2012; González Martínez 2020). Such choice is also a reason for the minimisation of negative readings of history. As we argue, the lack of reflection on tragic events, such as the drama of the Jewish diaspora as it could have appeared at Tilanqiao station shows the aim of reinforcing less conflicting discourses of harmony and the historical continuity of Shanghai's cosmopolitanism. Furthermore, we interpret the lack of references to Waitan as a sign of the missing resolution of the conflicting memory of this area after the extreme re-significations to which it was subject after 1949, during the Cultural Revolution, and from 1989 onwards (Zhu 2020).

Agreeing with Reynolds (2012), we also argue that there is a deeper social significance in the omissions. Recent literature on Shanghai has highlighted how the design and operation of metro infrastructures have made urban transportation more efficient, with an immediate positive impact on the conservation of the urban landscape (Wang 2021). According to this interpretation, the metro has spared the widening of roads in the city, alleviating the pressure on historic areas. However, on the other hand, we contend that the chronology of metro stations in listed areas illustrates the clash between conservation and transit-oriented models of development, where trains herald the arrival of new construction. This means an increase in density around metro stations, with an immediate effect on the real estate industry. Evidence above ground shows how this has frequently led to widespread demolition and the later gentrification of historic areas, which is currently ongoing in the surroundings of Tilanqiao and Laoximen stations (Tilanqiao and Laochengxiang listed areas, respectively).

We also need to highlight the notorious absence of references to certain areas, which inherently establishes firstclass and second-class heritage listed zones in Shanghai. For the cases of Yuyuan Road, Xinhua Road, and Hongqiao Road, we may argue a lack of geographical centrality that takes them out of the focus of preferred touristic routes. However, particularly significant is the case of the old city, with more than 800 years of history. Laochengxiang, with its rich architecture, characteristic landscape and long-term traditions, is poorly represented, with an only mural based on stereotypes of the 1930s. More startingly, this mural exists only at Yuyuan Garden station, one of the top tourist destinations in Shanghai, which is an area without residents since its commercial redevelopment in the late 1980s and early 1990s. In light of the state of neglect and recent evictions in the surroundings of the other two stations of Laochengxiang, Laoximen and Xiaonanmen (Fig. 13), this narrative gap announces a future without memory for the original seat of the city before the Concessions.

\section{Conclusions}

This research shows the complex, mirrored interaction between heritage listed areas and metro infrastructure as representative of China's heritage turn. In the underground space of the metro, a complete institutional apparatus builds and supports an authorized heritage discourse. According to it, the political, social and economic values of heritage defined from a top-down perspective are reformulated by conscious action, crystallised in nostalgic narratives of cosmopolitanism and future visions of social harmony. This image is clearly embedded, for example, in the architectural features of the shikumen. This vernacular housing typology is celebrated as a hybrid outcome of Chinese and Western building cultures that housed most of Shanghai's population during the twentieth century and the origins of Communism in China. Adding to these international and national narratives, the display of artworks in the 'unavoidable museum' of metro stations complies with its original educational function, confirming the role of heritage as a guide for citizens' moral and social conduct.

Our research shows how the cultural significance of heritage listed areas is unevenly represented in the heritage narratives present in the metro infrastructure, both above and below ground. We contend that this is a 


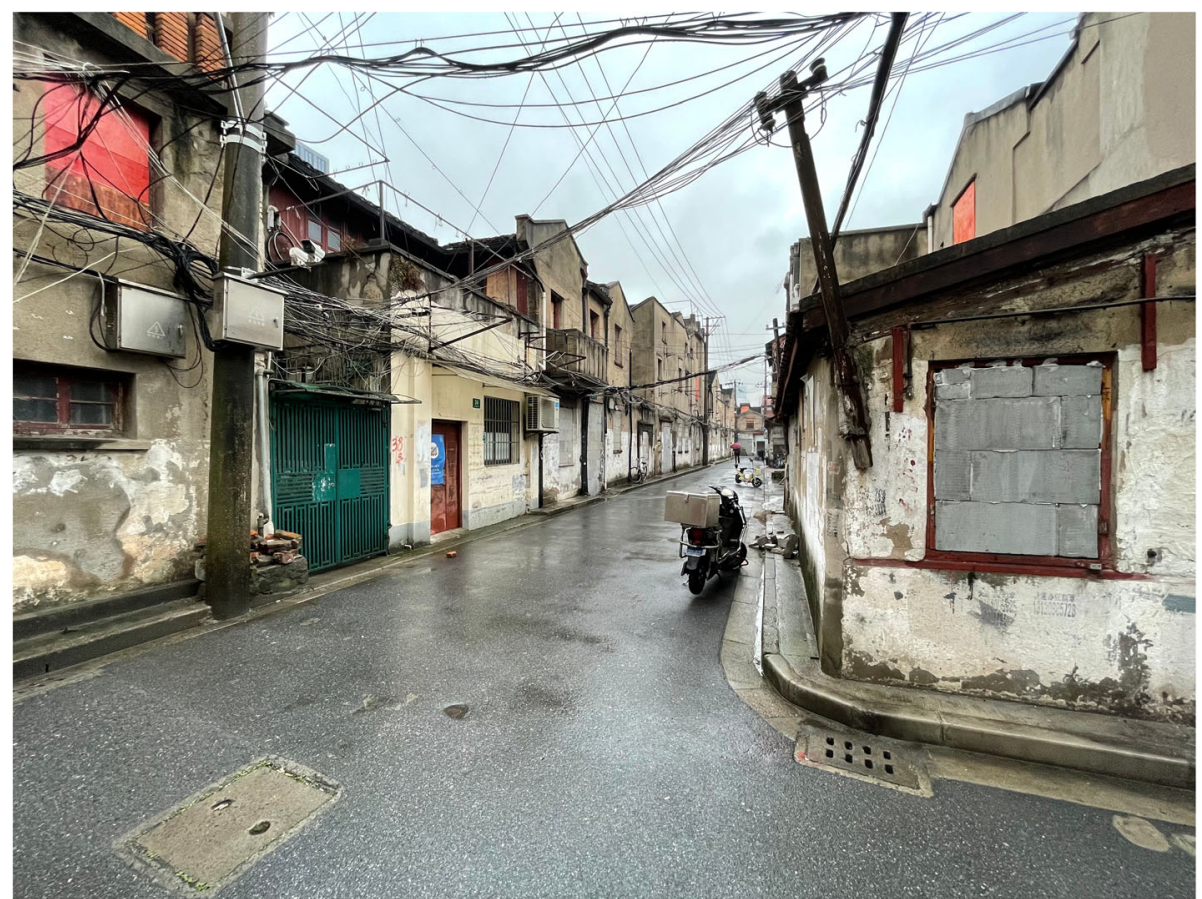

Fig. 13 Image of Wengjia Zhilong in the now empty Jinjiafang neighbourhood, approximately $150 \mathrm{~m}$ from Laoximen Station (Line 10) in the Laochengxiang listed area. (Source: the author)

mismatch between two important Foucauldian institutional apparatuses': on the one hand, the apparatus was established by the municipal heritage protection system in heritage listed areas after the vigorous listing initiative of 2003; on the other hand, the Shanghai Shentong Metro Group was established through the incorporation of cultural features in metro stations.

Despite the limitations that the 'white canvas' of metro stations may have as an unintended cultural venue, we interpret this mismatch as symptomatic of a clear purpose of image production based on selected narratives. As we argue, the narratives present in the metro are eluding the inherent contradictions of Shanghai's identity, a city that has undergone strong historical discontinuities throughout the 20th and 21st centuries and that has experienced a massive change in the last 40 years. In this sense, the omissions in the narratives displayed in metro stations also convey a clear message about the future tendencies of re-signification and even the disappearance of the heritage above ground, as the key case of Laochengxiang shows. The projected harmonious future of the city will be both dazzled by the lights of what is kept and haunted by the ghosts of what is left behind.

\section{Acknowledgements}

The author would like to thank the two anonymous reviewers and the Executive Editor of Built Heritage, Dr. Li Yingchun, for their insightful comments on the paper. The author also would like to acknowledge the fieldwork performed by the students of the course on Heritage Management and Legislation of the academic year 2019-2020 at the College of Architecture and Urban Planning of Tongji University: Xu Minhui, Duan Ziwei, Zhao
Yuxuan, Chen Hongyu, Xu Zhang, Jun Ng Kai, Si Ruolan, Jiang Shuhui, Su Jingyi, Yu Wanxuan, Zhou Xuejing, Jiang Zhihui, Lin Yuran, Zhou Peicheng and Wang Ziyu.

Author's contributions

Plácido González Martínez is the sole author. The author(s) read and approved the final manuscript.

\section{Funding}

The author received funding from the Eastern Scholar Program of the Shanghai Municipal Education Commission.

\section{Availability of data and materials}

Presented in the main paper and additional supporting files.

\section{Declarations}

Ethics approval and consent to participate Not applicable.

\section{Consent for publication}

Not applicable.

\section{Competing interests}

The author declares that the author has no competing interests.

Received: 10 November 2020 Accepted: 25 March 2021

Published online: 28 April 2021

\footnotetext{
References

Ashworth, G., and M. Karavatzis. 2011. Why Brand the Future with the Past? The Role of Heritage in the Construction and Promotion of Place Brand Reputations. In International Place Branding Yearbook 2011, ed. F.M. Go and R. Govers, 25-38. London: Palgrave Macmillan.

Athens Charter for the Restoration of Historic Monuments. 1931.

Clendenin, M. 2008. Hector Guimard, political movements, and the Paris metro: Natural sympathies, governing harmony, and social change. PhD diss., University of Pennsylvania.
} 
Domínguez Rubio, R., and U. Fogué. 2013. Technifying public space and publicizing infrastructures: Exploring New urban political ecologies through the square of general Vara del Rey. International Journal of Urban and Regional Research 37 (3): 1035-1052. https://doi.org/10.1111/1468-2427.12052.

Fouseki, K., and C. Sandes. 2009. Private preservation versus public presentation: The conservation for display of in situ fragmentary archaeological remains in London and Athens. Papers from the Institute of Archaeology 19: 37-54.

Gabriel, D. 2018. Revolution from 360 feet below: Form and ideology in the Pyongyang metro. Journal of Korean Studies 23 (1): 111-133. https://doi.org/1 0.1215/21581665-4339080

González Martínez, P. 2017. Urban authenticity at stake: A New framework for its definition from the heritage perspective at the Shanghai Music Valley. Cities 70: 55-64. https://doi.org/10.1016/j.cities.2017.06.017.

González Martínez, P. 2019. From verifiable authenticity to verisimilar interventions: Xintiandi, Fuxing $\mathrm{SOHO}$, and the alternatives to built heritage conservation in Shanghai. International Journal of Heritage Studies 25 (10): 1075-1092. https://doi.org/10.1080/13527258.2018.1557235.

González Martínez, P. 2020. Curating the selective memory of gentrification: The Wulixiang Shikumen Museum in Xintiandi, Shanghai. International Journal of Heritage Studies.: 1-17. https://doi.org/10.1080/13527258.2020.1821237.

Harrison, R. 2013. Forgetting to remember, remembering to forget: Late modern heritage practices, sustainability and the 'crisis' of accumulation of the past. International Journal of Heritage Studies 19 (6): 579-595. https://doi.org/10.1 080/13527258.2012.678371.

Huybrechts, E. 2018. The historic urban landscape and the Metropolis. Built Heritage 2 (4): 20-30 https://doi.org/10.1186/BF03545681.

ICOMOS. 1964. International Charter for the Conservation and Restoration of Monuments and Sites. http://www.icomos.org/charters/venice_e.pdf. Accessed 19 Sept 2020.

ICOMOS. 1987. Charter for the Conservation of Historic Towns and Urban Areas.

ICOMOS. 1994. The Nara document on authenticity.

ICOMOS. 2003a. The Hoi An declaration on conservation of historic districts of Asia.

ICOMOS. 2003b. Principles for the Analysis, Conservation and Structural Restoration of Architectural Heritage. https://www.icomos.org/charters/ structures_e.pdf. Accessed 19 Sept 2020.

ICOMOS. 2005. Xi'an Declaration on the Conservation of the Setting of Heritage Structures, Sites and Areas. https://www.icomos.org/xian2005/xian-declara tion.pdf. Accessed 19 Sept 2020.

Jansson, A., and A. Lagerkvist. 2009. The future gaze: City panoramas as politicoemotive geographies. Journal of Visual Culture 8 (1): 25-53 https://doi.org/1 $0.1177 / 1470412908100902$.

Labbé, M. 2016. Architecture of underground spaces: From isolated innovations to connected urbanism. Tunnelling and Underground Space Technology 55: 153-175. https://doi.org/10.1016/j.tust.2016.01.004.

Lambertucci, F. 2013. Digging in the past. Archaeology as a resource for Rome underground transit. In Advances in underground space development, ed. Y. Zhou, J. Cai, and R. Sterling, 170-181. Singapore: Research Publishing.

Lambertucci, F. 2016. Archaeo-mobility. Integrating archaeological heritage with everyday life. Procedia Engineering 165: 104-113. https://doi.org/10.1016/j. proeng.2016.11.741

Lambertucci, F. 2018. Archaeology for commuters. The san Giovanni Archaeostation on the New metro line $\mathrm{C}$ in Rome. Tunnelling and Underground Space Technology 78: 95-105. https://doi.org/10.1016/j.tust.2018.04.020.

Larsen, H.G. 2014. The emerging Shanghai City brand: A Netnographic study of image perception among foreigners. Journal of Destination Marketing \& Management 3 (1): 18-28. https://doi.org/10.1016/j.jdmm.2013.12.003.

Law, A. 2012. Postcolonial Shanghai: An urban discourse of prosperity and futurity. In Colonial frames, nationalist histories: Imperial legacies, architecture, and modernity, ed. M. Rajagopalan and M. Desai, 285-304. London and New York: Routledge.

Law, A., and Q. Qin. 2017. Searching for economic and cosmopolitan roots: The historical discourse of 'Hankou merchant port nostalgia' in the central Chinese City of Wuhan. METU Journal of the Faculty of Architecture. https:// doi.org/10.4305/METU.JFA.2017.2.14.

Li, N., C. Zhang, and Y. Guan. 2015. "Jiyu gongye sheji shijiao de Xi'an ditiezhan gonggong sheshi sheji tanxi." [Analysis of the Design of Public Facilities of Xi'an Metro Station Based On the Industrial Perspective.]. Journal of Xi'an University of Architecture and Technology (Nature Science Edition) 5: 766-770.

Ludwig, C., and L. Walton. 2020. Introduction: (un) authorised heritage discourse and practice in China. In The heritage turn in China: The reinvention, dissemination and consumption of heritage, ed. C. Ludwig, L. Walton, and Y. Wang, 15-36. Amsterdam: Amsterdam University Press. https://doi.org/10.23 07/j.ctv131bsxp.4

O'Mahony, M. 2003. Archaeological fantasies: Constructing history on the Moscow metro. The Modern Language Review 98 (1): 138-150. https://doi. org/10.2307/3738180.

Oakes, T. 2019. Making cultural cities in China: Governance, state-building, and precarious creativity. Environment and Planning A: Economy and Space 51(1): 178-186.

Pan, T. 2005. "Shanghai Nostalgia: Historical memory, community building and place making in a late socialist city." In Restructuring the Chinese City, edited by Laurence J.C. Ma and Fulong Wu. London: Routledge.

Regulations of Shanghai Municipality on the Protection of the Areas with Historical Cultural Features and the Excellent Historical Buildings. 2002.

Ren, X. 2008. Forward to the past: Historical preservation in globalizing Shanghai. City \& Community 7 (1): 23-43. https://doi.org/10.1111/j.1540-6040.2007.00239.x.

Reynolds, M. 2012. A glamorous gentrification: Public art and urban redevelopment in Hollywood, California. Journal of Urban Design 17 (1): 101115. https://doi.org/10.1080/13574809.2011.646246.

Rose, G. 2007. Visual methodologies. An introduction to the interpretation of visual materials. London: Sage Publications.

Ryklin, M. 2014. 'The best in the world': The discourse of the Moscow metro in the 1930s. In The landscape of Stalinism: The art and ideology of soviet space, ed. E. Dobrenko and E. Naiman, 261-276. Seattle: University of Washington Press.

Smith, L. 2006. Uses of heritage. Abingdon: Routledge. https://doi.org/10.4324/ 9780203602263.

Sun, J., B. Lin, and M. Yang. 2015. "Diyu wenhua zai ditiezhan kongjian sheji zhong de yingyong yanjiu-yi Xi'an Beijing weili." [Application of Regional Culture in The Design of Subway Station Space for Underground Railway: Taking Xi'an and Beijing for Example.]. Huazhong Architecture 9: 65-69.

Svensson, M., and C. Maags. 2018. Mapping the Chinese heritage regime. Ruptures, Governmentality and agency. In Chinese heritage in the making: Experiences, negotiations and contestations, ed. M. Svensson and C. Maags, 11-38. Amsterdam: Amsterdam University Press.

UNESCO. 1968. Recommendation concerning the preservation of cultural property endangered by public or private works.

UNESCO. 1976. Recommendation concerning the safeguarding and contemporary role of historic areas.

UNESCO. 2005. Vienna memorandum on world heritage and contemporary architecture-Managing the historic urban landscape.

UNESCO. 2011. Recommendation on the Historic Urban Landscape. http://whc. unesco.org/en/activities/638. Accessed 19 Sept 2020.

Wang, J. 2009. Art in capital: Shaping distinctiveness in a culture-led urban regeneration project in red town, Shanghai. Cities 26 (6): 318-330. https://doi. org/10.1016/j.cities.2009.08.002.

Wang, L. 2021. Evolution and characteristics of the urban heritage preservation system in Shanghai. Built Heritage in press.

Wu, W. 2004. Cultural strategies in Shanghai: Regenerating cosmopolitanism in an era of globalization. Progress in Planning 61 (3): 159-180. https://doi.org/1 0.1016/j.progress.2003.10.002.

Zhong, S. 2015. Artists and Shanghai's culture-led urban regeneration. Cities 56: 165-171.

Zhu, H., J. Qian, and Y. Gao. 2011. Globalization and the production of City image in Guangzhou's Metro Station advertisements. Cities 28 (3): 221-229. https:// doi.org/10.1016/j.cities.2010.12.004.

Zhu, Y. 2019. Politics of scale: Cultural heritage in China. In Politics of scale: New directions in critical heritage studies, ed. Y. Zhu, T. Lähdesmäki, and S. Thomas, $21-$ 35. New York, Oxford: Berghahn Books. https://doi.org/10.2307/j.ctv12pnscx.6.

Zhu, Y. 2020. From Colonialism to Cosmopolitanism: Heritage Making of the Bund in Shanghai. In Presentation held at the 2020 ACHS: Futures Conference.

Zhu, Y., and C. Maags. 2020. Introduction. The power of the past. In Heritage politics in China. The power of the past, ed. Y. Zhu and C. Maags, 1-23. London and New York: Routledge. https://doi.org/10.4324/9780429446429-1.

Zhuang, R. 2000. "Chengshi ditie chezhan sheji." [Urban Subway Station Design.]. Time + Architecture 4: 18-21.

\section{Publisher's Note}

Springer Nature remains neutral with regard to jurisdictional claims in published maps and institutional affiliations. 